\title{
Soft shell clams Mya arenaria with disseminated neoplasia demonstrate reverse transcriptase activity
}

\author{
M. L. House ${ }^{1, *}$, C. H. Kim ${ }^{2}$, P. W. Reno ${ }^{1}$ \\ ${ }^{1}$ Fish Disease Laboratory, Coastal Oregon Marine Experiment Station, Hatfield Marine Science Center, \\ Oregon State University, Newport, Oregon 97365, USA \\ ${ }^{2}$ Department of Microbiology, Oregon State University, Corvallis, Oregon 99331-3804, USA
}

\begin{abstract}
Disseminated neoplasia (DN), a proliferative cell disorder of the circulatory system of bivalves, was first reported in oysters in 1969. Since that time, the disease has been determined to be transmissible through water-borne exposure, but the etiological agent has not been unequivocally identified. In order to determine if a viral agent, possibly a retrovirus, could be the causative agent of DN, transmission experiments were performed, using both a cell-free filtrate and a sucrose gradientpurified preparation of a cell-free filtrate of DN positive materials. Additionally, a PCR-enhanced reverse transcriptase assay was used to determine if reverse transcriptase was present in tissues or hemolymph from DN positive soft shell clams Mya arenaria. DN was transmitted to healthy clams by injection with whole DN cells, but not with cell-free filtrates prepared from either tissues from DN pusitive clams, or DN cells. The cell-free preparations from DN-positive tissues and hemolymph having high levels of DN cells in circulation exhibited positive reactions in the PCR-enhanced reverse transcriptase assay. Cell-free preparations of hemolymph from clams having low levels of DN $<0.1 \%$ of cells abnormal), hemocytes from normal soft shell clams, and normal soft shell clam tissues did not produce a positive reaction in the PCR enhanced reverse transcriptase assay.
\end{abstract}

KEY WORDS: Soft shell clam - Mya arenaria Disseminated neoplasia Reverse transcriptase activity

\section{INTRODUCTION}

Disseminated neoplasia (DN) is a progressive and lethal condition of bivalves characterized by the presence of neoplastic cells in the animal's circulatory system and tissue spaces. This disease was first described in native Pacific oysters Ostreola conchaphila by Jones \& Sparks (1969). Since then, the condition has been described in at least 15 species of bivalves over a wide geographic distribution (Peters 1988, Elston et al. 1992). Prevalence of DN in certain locations has been reported to reach $90 \%$ (Reinisch et al. 1984). The disease is transmissible to healthy animals by waterborne exposure to DN-positive animals (Brown 1980, Appeldoorn et al. 1984, Elston et al. 1988, House 1997). Laboratory experiments using several species of bi-

\footnotetext{
- Present address: Western Fisheries Research Center, United States Geological Survey, 6505 NE 65th St., Seattle, Washington 98115, USA. E-mail: marcia_house@usgs.gov
}

valves have shown that $\mathrm{DN}$ can be transplanted to healthy animals of the same species by the injection of hemolymph taken from animals with high numbers of DN cells in circulation (Farley et al. 1986, Elston et al. 1988, Twomey \& Mulcahy 1988). Transmission of the disease via an unfiltered homogenate of DN cells from mussels Mytilus edulis was successful within the same species (Elston et al. 1988, Kent et al. 1991, Moore 1993).

Oprandy et al. (1981) reported that a virus with the physical and morphological characteristics of a type B retrovirus was observed by transmission electron microscopy of tissue from DN-positive soft shell clams Mya arenaria. They reported successful transmission of DN using a cell-free filtrate prepared from DNpositive clams, and that Koch's postulates had been fulfilled by recovering virus from clams that developed the disease following injection, and re-infecting disease-free clams with this material. Although these results suggested that DN in $M$. arenaria was caused 
by a retroviral agent, attempts to repeat this work have not been successful (Elston et al. 1992), and therefore, the evidence for a retroviral etiology remains unsubstantiated. Transmission of DN using cell-free filtrates has been attempted, unsuccessfully, in mussels (Moore 1993) and soft shell clams (McLaughlin et al. 1992), which were demonstrated to be susceptible to transplantation of DN by whole cell injection.

The difficulty in conducting long-term transmission experiments with bivalves was recognized by Elston et al. (1992), who specifically cited the need to provide the animals with food and water free of potential infectious agents over the extended course of the experiment. The capacity to provide high quality filtered seawater and cultured algae as a food source at the Hatfield Marine Science Center in Newport, Oregon, USA, enabled us to maintain soft shell clams in the laboratory for more than a year (House 1997), which encompassed the duration of the experiments reported here.

Reverse transcriptase (RT) is an enzyme essential to retroviral replication and has been used as an indicator for the presence of a retrovirus (Maramorosch \& Koprowski 1977). Early attempts to determine if RT was present in DN tissues provided equivocal results (Brown 1980).

The objectives of the work presented here were to determine if DN could be transferred from Mya arenaria by injection of cell-free filtrates from tissues from DN-positive clams or hemolymph containing DN cells and to determine if retroviral elements, specifically $R T$, were present in clams with DN.

\section{METHODS}

Experimental animals. Soft shell clams Mya arenaria (average valve length $=43 \mathrm{~mm}$ ) were collected from Alsea Bay, Oregon. Hemolymph samples $(0.1 \mathrm{ml})$ were drawn from the anterior adductor muscle sinus and placed on coverslips coated with $0.05 \%$ poly-L-lysine and allowed to settle for $30 \mathrm{~min}$ at room temperature before fixation with $1 \%$ glutaraldehyde $/ 4 \%$ formaldehyde in sea water. All clams were screened for DN cells, and were negative at the initiation of the experiment.

Detection of DN. Hemolymph samples fixed to a microscope slj.de were stained with a monoclonal antibody against a neoplastic cell epitope (Smolowitz \& Reinisch 1986), generously provided by Dr Carol Reinisch, Tufts Veterinary College, Grafton, Massachusetts, USA. Bound antibody was detected using the Vectastain ABC-AP Kit (Vector Laboratories, Burlington, CA, USA); samples were counterstained with hematoxylin and mounted. Cells staining red were considered DN positive while normal cells stained blue. At least 1000 cells per clam were examined at $400 \times$. The percentage of DN cells in the sample was recorded.

First transmission experiment. Disease-free Mya arenaria were divided into treatment groups of 20 clams each: a negative control group injected with sterile sea water, a positive control group injected with $10^{55}$ whole DN cells, and 2 groups injected in the anterior adductor sinus with a cell-free homogenate preparation, either unfiltered or filtered, as described below.

The inocula for the latter 3 groups were prepared from hemolymph drawn from a pool of 20 clams with $99 \%$ DN circulating cells $\left(6.5 \times 10^{6}\right.$ cells $\left.\mathrm{ml}^{-1}\right)$. The hemolymph was sonicated on ice for five $30 \mathrm{~s}$ intervals at $50 \%$ duty cycle with $2 \mathrm{~min}$ rests between intervals, then centrifuged at $10000 \times g$ for $30 \mathrm{~min}$ at $4^{\circ} \mathrm{C}$ to remove whole cells and microsomes. A subsample of the supernatant was examined using phase-contrast microscopy, and no intact cells were detected. A portion was reserved and was injected as the cell-free homogenate treatment. The remaining supernatant was filtered through a $0.45 \mu \mathrm{m}$ pore size filter, and $0.1 \mathrm{ml}$ injected as the filtrate treatment.

Following inoculation, clams were held in tanks supplied with $0.2 \mu \mathrm{m}$ filtered sea water throughout the course of the experiment (temperature range: 10 to $17^{\circ} \mathrm{C}$ ). The clams were fed 11 of a 50/50 mixture of cultured Isochrysis galabana and Chaetoceros calcitrans $\left(7 \times 10^{5}\right.$ to $1.2 \times 10^{6}$ cells $\left.\mathrm{ml}^{-1}\right)$ on a daily basis. Tanks were monitored for mortalities over the next 12 mo. Hemolymph samples were taken at $0,4,7,8,10,11$ and 12 mo and analyzed for the presence of DN cells using immunocytochemistry.

Second transmission experiment. A second transmission experiment was performed to test the transmissibility of DN using a sucrose gradient purified preparation of a cell-free filtrate. A positive control group of 15 clams was injected with whole DN cells, and a negative control group of 15 clams was injected with sterile Tris-buffered saline with EDTA (TNE: $10 \mathrm{mM}$ Tris $\mathrm{pH} 7.4,400 \mathrm{mM} \mathrm{NaCl}$ and $1 \mathrm{mM}$ EDTA; Oprandy et al. 1981). Treatment inocula consisted of fractions from sucrose gradients containing material from DN cells, DN tissue, normal cells and normal tissue prepared by the method of Oprandy et al. (1981) as described below. Each treatment was injected into the adductor sinus of 20 clams in a volume of $0.1 \mathrm{ml} \mathrm{clams}{ }^{-1}$.

Following injection, the clams were held as described in the first experiment. Mortalities were monitored over the next $10 \mathrm{mo}$. Hemolymph samples were drawn at $0,3,5,6,8,9$ and 10 mo and analyzed for the presence of DN cells.

Sucrose gradient purification. Transmission study inocula: Preparation of transmission study inocula and PCR enhanced reverse transcriptase (PERT) was per- 
formed in the following manner. Hemolymph from 15 clams with $>95 \%$ DN cells in circulation was collected and pooled $\left(8 \times 10^{6}\right.$ cells $\left.\mathrm{mi}^{-1}\right)$. The DN tissue sample used for the PERT assay consisted of the soft tissue, with the siphons removed, of 2 clams with $>95 \%$ DN cells in circulation.

Control inocula were prepared from cells and tissues collected from 20 clams that were free of DN as shown by immunocytochemistry. The pooled hemolymph was centrifuged at $1500 \times g$ for $5 \mathrm{~min}$, and the soft pellet of hemocytes was resuspended in $8.5 \mathrm{ml}$ normal hemolymph to provide a cell concentration approximately equal to that of the DN sample $\left(2.1 \times 10^{6}\right.$ cells $\left.\mathrm{ml}^{-1}\right)$. The soft tissues, minus the siphons, of 2 clams were combined and used in the tissue sample.

Tissue and hemolymph samples were frozen at $-70^{\circ} \mathrm{C}$ then thawed at $4^{\circ} \mathrm{C}, 3$ times. The samples were maintained at $4^{\circ} \mathrm{C}$ for the rest of the procedure. Samples were diluted in sterile TNE to $20 \% \mathrm{v} / \mathrm{v}$ (cells) or $w / v$ (tissue). The samples were then homogenized in a blender and clarified by centrifugation at $10000 \times g$ for $30 \mathrm{~min}$, filtered through a $0.45 \mu \mathrm{m}$ filter, and centrifuged at $100000 \times g$ for $90 \mathrm{~min}$. The pellet was resuspended in $5 \%$ sucrose in TNE, and placed onto a discontinuous gradient of 15,35 , and $50 \%$ sucrose in TNE then centrifuged at $100000 \times g$ for $90 \mathrm{~min}$ in an SW 50.1 rotor (Beckman, Palo Alto, CA). The interface between the 35 and $50 \%$ sucrose layers was removed and diluted to $10 \% \mathrm{v} / \mathrm{v}$ with TNE, and centrifuged at $100000 \times g$ for $90 \mathrm{~min}$. The resulting pellet was resuspended in $5 \%$ sucrose in TNE, and placed onto a 10 to $60 \%$ continuous sucrose gradient. The gradient was centrifuged at $100000 \times g$ for $90 \mathrm{~min}$. Fractions $(0.5 \mathrm{ml})$ were taken from the gradient and the average density of the fractions was determined. Based on the results of Oprandy et al. (1981), 3 fractions in the range of $1.17 \mathrm{~g} \mathrm{ml}^{-1}$ (1.14 to $\left.1.20 \mathrm{~g} \mathrm{ml}^{-1}\right)$ were used as the inoculum. A $125 \mu \mathrm{l}$ portion of each fraction was removed and processed for analysis in the PERT assay described below. To prepare inocula, the fractions were combined, and the volume was brought to $2 \mathrm{ml}$ with sterile TNE. Each of the 20 clams in the treatment groups was injected with $0.1 \mathrm{ml}$ of the appropriate inoculum.

Reverse transcriptase assay samples: Samples that had been set aside for RT analysis by the PERT assay were diluted with $5.4 \mathrm{ml}$ of TNE, and centrifuged at $100000 \times g$ for $90 \mathrm{~min}$. The supernatant was discarded, and the pellet was resuspended in $20 \mu \mathrm{l}$ glycerol-based sample buffer (Pyra et al. 1994) (50 mM KCl, $25 \mathrm{mM}$ Tris-HCl, pH 7.5, 5 mM dithiothreitol, 0.25 mM EDTA, $0.025 \%$ Triton $X-100$, and $50 \%$ glycerol), and stored at $-20^{\circ} \mathrm{C}$.

In addition to samples prepared from the inocula for the transmission study, samples were prepared from other clams for RT analysis in the same manner, with the exceptions that the material was homogenized with a Dounce homogenizer on ice, and the pellet resulting from the discontinuous sucrose gradient was used in the PERT assay. Also, hemolymph samples were drawn from 3 recipient clams in each of the transmission study groups 5 mo post-injection (PI) and analyzed by the PERT assay.

Finally, continuous sucrose gradients were prepared using material from DN cells and normal hemocytes. Fractions with the buoyant density from 1.17 to $1.19 \mathrm{~g}$ $\mathrm{ml}^{-1}$ were divided for analysis with the PERT assay and examination with transmission electron microscopy (TEM). The TEM samples were negatively stained with phosphotungstic acid.

Reverse transcriptase assay. A sensitive, PCR-based assay described by Pyra et al. (1994), with modification of the temperature and incubation time of the first strand synthesis, was used to determine the presence of RT activity. Briefly, the PERT assay uses a singlestranded RNA template, MS2, and an MS2-specific primer $(\mathrm{RT}-1)$ to detect the presence of RT. The sample, prepared as described, was added to the first strand synthesis reaction, incubated at $15^{\circ} \mathrm{C}$ for $5 \mathrm{~h}$, then RNase was then added to degrade the RNA in the RNA/DNA hybrid. If RT was present in the sample, MS2 cDNA was synthesized. Next, a second MS2 specific primer (RT-2) and an additional amount of RT-1 were added along with Taq polymerase and PCR was performed to amplify the MS2 cDNA. After the PCR products were run on an agarose gel and transferred to nitrocellulose by Southern blotting (Southern 1975), an internal probe (RT-3) was used to show the specificity of the product. The presence of a band in the Southern blot indicated that RT was present in the sample.

Sensitivity of PERT assay. In order to determine the sensitivity of the PERT assay, $2 \mathrm{ml}$ hemolymph samples were collected from clams with $100 \%, 1 \%$ and $0.1 \% \mathrm{DN}$ and processed as described above. Additionally, a series of samples of varying concentrations of DN cells were prepared by combining hemolymph from clams with $>99 \%$ DN cells with hemolymph from normal clams to give concentrations of $100,50,10,1,0.1$ and $0 \%$ DN cells. The samples were treated as those in the preparation of transmission study inocula and other PERT samples.

\section{RESULTS}

\section{First transmission experiment}

In the first experiment, samples collected at 4 mo post-injection (PI) from clams injected with $10^{5.5} \mathrm{DN}$ cells showed that $100 \%(14 / 14)$ of the surviving clams were positive for DN. None of these animals survived until the next sampling time at 7 mo PI. 
No other clams in this experiment developed DN. Neither the negative controls nor the clams injected with the cell-free homogenate, nor the cell-free filtrate prepared from DN cells showed detectable DN through the 12 mo course of the experiment. Survival was greater than $50 \%$ in each of these groups at termination of the experiment.

\section{Second transmission experiment}

In the second transmission experiment, Mya arenaria in the group injected with whole cells developed DN. At 3 mo PI, $44 \%(4 / 9)$ of the clams were positive for DN. In the samples taken at 5,6 , and $8 \mathrm{mo} \mathrm{PI}, 83 \%$ $(5 / 6), 100 \%(6 / 6)$ and $100 \%(4 / 4)$, respectively, were positive for DN. No clams in this group were alive at 9 mo post-injection.

No clams injected with gradient purified material from highly DN positive clam tissues, DN cells, normal soft shell clam tissues, or normal soft shell clam hemocytes developed DN. At the completion of the 10 mo experiment, survival was $70 \%$ or greater in groups that were injected with the sucrose gradient purified preparations, and $60 \%$ in the negative control group.

\section{Reverse transcriptase assay}

Samples prepared from DN positive clams produced evidence for the presence of RT activity. As shown in Fig. 1, a $112 \mathrm{bp}$ PCR product was obtained using samples from the $35 / 50 \%$ sucrose interface of the discontinuous gradients prepared from soft tissues of animals with DN (lane 2), as well as from samples of DN cells in the hemolymph (lane 4). The fractions from the continuous sucrose gradients having buoyant densities of

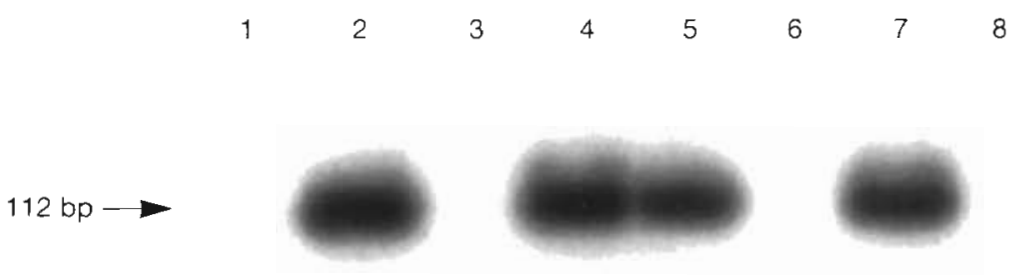

Fig. 1. Detection of PCR products labeled with ${ }^{32} \mathrm{P}$ in the PERT assay. Lane 1: unlabeled $100 \mathrm{bp}$ ladder (BRL). Lanes 2-4: PERT assay products prepared from the $35 / 50 \%$ sucrose gradient interface of material from DN tissue (lane 2), normal soft shell clam tissue (lane 3), and DN cells (lane 4). Lanes 5-8: PERT assay products from material in continuous gradient fractions prepared from: DN tissue (lane 5), normal soft shell clam tissue (lane 6), DN cells (lane 7), and normal soft shell clam hemocytes (lane 8)
1.17 to $1.19 \mathrm{~g} \mathrm{~m}^{-1}$ that were used in the transmission experiment also indicated the presence of RT in DN tissue (lane 5), and in hemolymph containing DN cells (lane 7). No PCR products were detected in material prepared from normal clam tissues collected from the interface of the discontinuous gradient (lane 3), or from fractions of the continuous gradients containing material prepared from normal clam tissues or normal clam hemocytes (lanes 6 and 8, respectively).

When hemolymph samples were taken from clams with known levels of DN as determined by immunocytochemistry, the PERT assay detected RT activity in clams with high $(100 \%)$ and moderate $(1 \%)$, but not with a very low number $(0.1 \%)$ of DN cells (Fig. 2, lanes 2,3 , and 4, respectively). Similarly, samples of hemolymph from a clam with $>99 \%$ DN cells diluted with normal hemocytes to concentrations of $50 \%$, $10 \%$, and $1 \%$ DN cells (lanes 5, 6, 7 and 8 respectively), prouced PCR products indicative of RT activity, but at $0.1 \%$ DN cells (lane 9) there was no detectable RT activity. The 112 bp PCR product was absent in the negative control sample of normal hemocytes (lane 10).

Hemolymph samples taken at 5 mo post-injection from clams injected with the preparation from sucrose gradients in the second transmission study had no detectable PCR products. The absence of RT activity in these samples indicates that the RT activity was only associated with the presence of DN cells in clams that were successfully infected.

Samples from fractions of the sucrose gradients which were positive for RT activity by the PERT assay were examined by transmission electron microscopy after negative staining with phosphotungstic acid. No structures resembling virus particles were observed.

\section{DISCUSSION}

Disseminated neoplasia was transmitted to healthy soft shell clams by direct injection of whole DN cells, but not by injection of cell-free preparations of either DN cells or tissues taken from DN-affected clams. The results of the transmission studies presented here, in addition to those using cellfree filtrates in soft shell clams (McLaughlin et al. 1992) and mussels (Moore 1993) in which transmission was not successful, do not support the results of Oprandy et al. (1981), who reported transmission of $\mathrm{DN}$ in soft shell clams with a cell-free filtrate. 


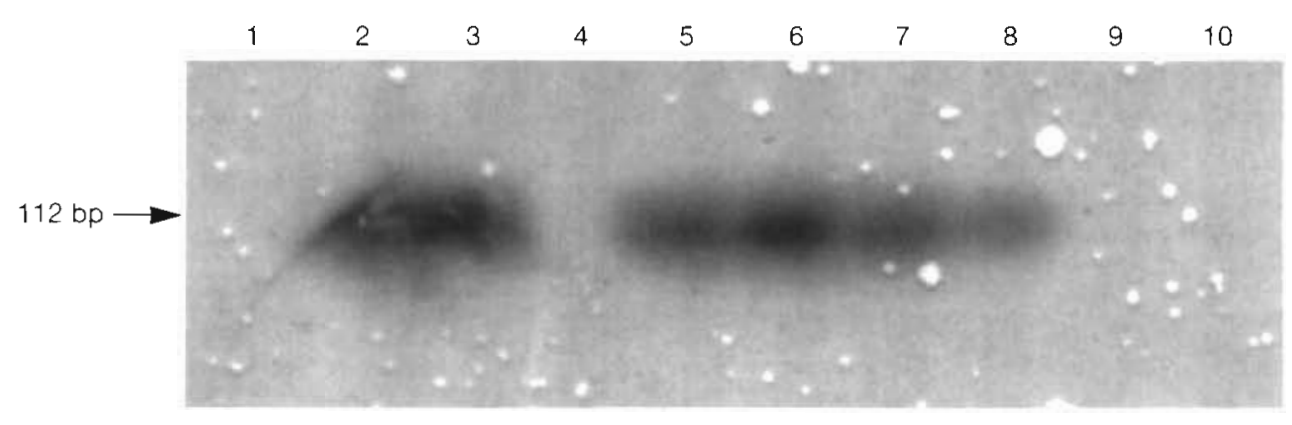

Fig. 2. Sensitivity of PERT assay using hemolymph samples labeled with ${ }^{32}$ P. Lane 1 unlabeled 100 bp ladder (BRL). Lanes $2-4$ : PERT assay products from samples prepared from hemolymph collected from clams with known levels of DN: 100\% DN (lane 2), 1\% DN (lane 3), and 0.1\% DN (lane 4). Lanes 5-10: PERT assay products from hemolymph preparations with decreasing proportions of DN cells diluted in normal soft shell clam hemocytes: $100 \%$ DN (lane 5), 50\% DN (lane 6), $10 \%$ DN (lane 7), $1 \%$ DN (lane 8), $0.1 \%$ DN (lane 9), and normal soft shell clam hemocytes (lane 10)

In work done to determine if disease development was affected by the number of cells injected, House (1997) found that DN could be successfully transmitted by injection of as few as $10^{46}$ whole DN cells injected into the adductor sinus of susceptible clams. In the protocol used in the current study, centrifugation would remove not only whole cells, but also the microsomal fraction of lysed cells. This may have reduced the concentration of a putative virus to a level below the threshold necessary to initiate infection, although RT activity could still be detected. Alternatively, the procedures used during purification may have removed or inactivated a highly labile infectious agent. Retroviruses can be cell-associated (Evermann 1990), and the removal of membranous material by centrifugation may have effectively removed virus. Elston et al. (1988), Kent et al. (1991), and Moore (1993) successfully transmitted DN from DN-positive mussels to disease-free mussels with a cell-free homogenate that included membranous material. If a virus could not be freed from the cell membrane by the methods utilized here, it could have been lost in the preparation of the inoculum.

Early attempts to detect RT in bivalves with DN were equivocal (Brown 1980, Appeldoorn et al. 1984), but the more sensitive methods used here indicated that RT activity was present in DN cells. Medina et al. (1993) reported detection of RT in soft shell clams. The enzyme was reported to be active at $6^{\circ} \mathrm{C}$ and inactive above $25^{\circ} \mathrm{C}$, but only limited information was available concerning the methods of detection that were used. In our studies, the temperature for the PERT assay was $15^{\circ} \mathrm{C}$. This study provides evidence that while RT is present in DN cells and tissues of affected clams, it is absent from clams which are known to be DN negative.

The PERT assay did not detect RT in hemolymph samples from clams with a low proportion of DN cells in circulation $(<1 \%)$, nor in samples that were diluted with normal cells to contain $0.1 \%$ or fewer DN cells. Although the clams used in the PERT study were judged DN positive by immunohistochemical and morphological evaluation, they may have been below the level of detection by the PERT assay, even though the method has been shown to be quite sensitive in other systems (Pyra et al. 1994). Another possible source of RT activity could be mycoplasma (Maramorosch \& Koprowski 1977); however, the absence of RT activity in negative clams suggests that RT activity was associated with the infectious process that results in DN. Further studies will be required to determine the source of the RT activity in the DN positive materials.

Oprandy et al. (1981) observed what they interpreted to be a type $B$ retrovirus in a negatively stained sample of a sucrose gradient preparation from DN positive Mya arenaria. As reviewed in Elston et al. (1992), several other electron microscopy studies have failed to detect the presence of viral particles associated with DN in $M$. arenaria (Farley 1976, Appeldoorn et al. 1984), Mytilus edulis (Mix et al. 1979, Moore 1993), or Cerastoderma edulis (Auffret \& Poder 1986). The samples that were examined by negative staining techniques in this study were likewise negative for virus-like particles.

Studies pursuing the source of the RT activity in DN positive materials will be essential to determining the etiological agent of this disease. RT assays alone are not enough to confirm that a retrovirus is the causative agent of DN, and transmission studies and visualization of viral particles using EM have not proven convincing. The development of marine invertebrate cell culture systems could advance the study of DN by potentially allowing isolation and characterization of a viral agent. Determining the temperature range of the RT activity using the PERT assay could lead to a better 
understanding of the seasonal nature of the disease that has been reported by several authors (Cooper et al. 1982, Appeldoorm et al. 1984, Farley et al. 1986, Brousseau 1987, Leavitt et al. 1990). Additionally, testing mussels and cockles with DN for RT activity using the methods described here would determine if the same patterns of enzyme activity existed, and potentially, if similar mechanisms are responsible for this condition in different species of bivalves.

Acknowledgements. We thank Dr James Casey, Dr Jo-Ann Leong and Dr James Winton for their helpful scientific discussions. In addition, we thank Dr Lavern Weber for his support at the Hatfield Marine Science Center. This research was funded by USDA grant number 91-34123-6123 and Oregon Agriculture Experiment Station Grant number AGS 280.

\section{LITERATURE CITED}

Appeldoorn R, Brown CW, Brown RS, Chang PW, Cooper K, Lorda E, Saila SB, Walker H, Wolke RE (1984) Field and laboratory studies to define the occurrence of neoplasia in the soft shell clam, Mya arenaria. API Publ no. 4345, Graduate School of Oceanography, University of Rhode Island, Kingston

Auffret M, Poder M (1986) Sarcomatous lesion in the cockle Cerastoderma edule. II. Electron microscopical study. Aquaculture 58:9-15

Brousseau DJ (1987) Seasonal aspects of sarcomatous neoplasia in Mya arenaria (soft-shell clam) from Long Island Sound. J Invertebr Pathol 57:269-276

Brown RS (1980) The value of the multidiciplinary approach to research on marine pollution effects as evidenced in a three year study to determine the etiology and pathogenesis of neoplasia in the soft-shell clam, Mya arenaria Rapp PV Reun Cons Int Explor Mer 179:125-128

Cooper KR, Brown RS, Chang PW (1982) The course and mortality of a hematopoetic neoplasm in the soft-shell clam, Mya arenaria. J Invertebr Pathol 39:149-157

Elston RA, Kent ML, Drum AS (1988) Transmission of hemic neoplasia in the bay mussel, Mytilus edulis, using whole cells and cell homogenate. Dev Comp Immunol 12: $719-727$

Elston RA, Moore JD, Brooks K (1992) Disseminated neoplasia of bivalve molluscs. Rev Aquat Sci 6(5,6):405-466

Evermann JF (1990) Comparative features of retroviral infections of livestock. Comp Immunol Microbiol Infect Dis 13(3):127-136

Farley CA (1976) Proliferative disorders in bivalve mollusks. Mar Fish Rev 1210:30-33

Farley CA, Otto SV, Reinisch CL (1986) New occurrence of

Editorial responsibility: Albert Sparks,

Seattle, Washington, USA epizootic sarcoma in Chesapeake Bay soft shell clams, Mya arenaria. Fish Bull US 84:851-857

House ML (1997) Transmission of disseminated neoplasia in the soft shell clam, Mya arenaria. PhD thesis, Oregon State University, Corvallis

Jones EJ, Sparks AK (1969) A.n unusual histopathological condition in Ostrea lurida from Yaquna Bay, Oregon. Proc Natl Shellfish Assoc 59:11

Kent ML, Wilkinson MT, Drum AS, Elston RA (1991) Failure of transmission of hemic neoplasia of bay mussels, Mytilus trossulus, to other bivalve species. J Invertebr Pathol 57 . $435-436$

Leavitt DF, Capuzzo JM, Smolowitz RM, Miosky DL, Lancaster BA, Reinisch CL (1990) Hematopoetic neoplasia in Mya arenaria: prevalence and indices of physiological condition. Mar Biol 105:313-321

Maramorosch K, Koprowski H (1977) Methods in virology. Academic Press, New York

McLaughlin SM, Farley CA, Hetrick FM (1992) Transmission studies of sarcoma in the soft-shell clam. Mya arenaria. In Vivo 6:367-370

Medina DJ, Paquette GE, Sadasiv EC, Chang PW (1993) Isolation of infectious particles hdving reverse transcriptase activity and producing hematopoetic neoplasia in Mya arenaria. J Shellfish Res 12(1):112-113

Mix MC. Hawkes JW, Sparks AK (1979) Observations on the ultrastructure of large cells associated with putative neoplastic disorders of mussels, Mytilus edulis, from Yaquina Bay, Oregon. J Invertebr Pathol 34:41-56

Moore JD (1993) Pathogenesis of disseminated neoplasia in eastern Pacific mussel, Mytilus trossulus. PhD thesis, University of Washington, Seattle

Oprandy JJ, Chang PW, Pronovost AD, Cooper KR, Brown RS, Yates VJ (1981) Isolation of a viral agent causing hematopoietic neoplasia in the soft-shell clam, Mya arenaria. $\mathrm{J}$ Invertebr Pathol 38:45-51

Peters EC (1988) Recent investigations on the disseminated sarcomas of marine bivaive molluscs. Am Fish Soc Spec Publ 18:74-92

Pyra H, Boni J, Schupbach J (1994) Ultrasensitive retrovirus detection by a reverse transcriptase assay based on product enhancement. Proc Natl Acad Sci USA 91. $1544-1548$

Reinisch CL, Charles AM, Stone AM (1984) Epizootic neoplasia in soft shell clams collected from New Bedford Harbor. Hazardous Waste 1(1):73-81

Smolowitz RM, Reinisch CL (1986) Indirect peroxidase staining using monoclonal antibodies specific for Mya arenaria neoplastic cells. J Invertebr Pathol 48:139-145

Southern EM (1975) Detection of specific sequences among DNA fragments separated by gel electrophoresis. J Mol Biol 98:503-517

Twomey E, Mulcahy MF (1988) Transmission of a sarcoma in the cockle Cerastoderma edule (Bivalvia: Mollusca) using cell transplants. Dev Comp Immunol 12:195-200

Submitted: April 1, 1998, Accepted: July 7, 1998

Proofs received from author(s): October 16, 1998 